๑О. Р. Боярчук, В. О. Косовська, Т. М. Косовська

ДВНЗ «Тернопільсъкий державний медичний університет ілені І. Я. Горбачевсъкого МОЗ України»

\title{
ОСОБЛИВОСТІ ПЕРЕБІГУ МУКОВІСЦИДОЗУ В ДІТЕЙ ТЕРНОПІЛЬСЬКОЇ ОБЛАСТІ
}

Мета дослідження - встановити особливості клінічного перебігу муковісцидозу в дітей Тернопільської області.

Матеріали та методи. Проведено ретроспективний аналіз історій хвороб 15 дітей Тернопільської області, хворих на муковісцидоз. Оглянуто 5 дітей під час їх перебування у стаціонарі.

Результати дослідження та їх обговорення. Ідеальними можна вважати виявлення хворих на муковісцидоз під час неонатального скринінгу і початок лікування одразу ж після встановлення діагнозу навіть за відсутності клінічних проявів. Діагноз муковісцидозу в усіх пацієнтів підтверджено в Західноукраїнському спеціалізованому дитячому медичному центрі. При дослідженні генотипу було виявлено різні види мутацій, але найчастіше траплялась мутація F508del/F508del. Mи визначили, що більшість дітей досягла десятирічного віку. Час встановлення діагнозу муковісцидозу був різний: до 1 року - в 2 дітей (13,3 \%), від 2 до 5 років - у 5 дітей (33,3 \%), від 5 до 10 років - у 8 дітей (53,4 \%). Встановлено, що, чим пізніше у хворого діагностують захворювання, тим тяжчий його перебіг і нижча ефективність лікування. У цих дітей відмічали багаторазові рецидиви запальних процесів у бронхах - у 10 хворих (66,6 \%), додаткових пазухах носа - в 5 (33,3 \%), порушень фоункції підшлункової залози - у 15 (100,0 \%), розвиток резистентності патогенної мікрофрлори до антибіотиків - у 15 (100,0%). Тому в цих дітей лікування ускладнювалось і, відповідно, ефективність його знижувалась. Майже в половини пацієнтів, а саме у 7 (46,6 \%), внаслідок тривалої гіпоксії виявлено десормацію пальців і нігтів у вигляді «барабанних паличок» та «годинникових скелець». Легеневу гіпертензію діагностовано в 4 пацієнтів (26,6 \%). Десормацію грудної клітки (бочкоподібна, розширена в передньо-задньому розмірі) відмічено в 7 дітей (46,6 \%). Холестатичний гепатит виявлено в 5 хворих (33,3 \%). Порушення толерантності до глюкози діагностовано у 2 дітей (13,3 \%).

Висновки. У структурі хворих на муковісцидоз дітей Тернопільської області переважають дівчатка та мешканці сільської місцевості. На сьогодні більша частина дітей області з муковісцидозом $(53,3 \%)$ досягла віку старше 10 років. У дітей нашого регіону переважає мутація F508del/F508del (66,7 \%). У більшості дітей $(53,4 \%)$ захворювання було діагностовано після 5 років. У дебюті хвороби найчастіше спостерігали затяжні обструктивні бронхіти $(66,7$ \%) та порушення фрункції підшлункової залози (100,0%). Серед ускладнень переважали кісткові деформації, ознаки хронічної гіпоксії та висока частота інфрікування золотистим стафрілококом (73,3 \%) і синьогнійною паличкою $(46,7$ \%). Необхідно збільшити настороженість щодо діагностики муковісцидозу на ранніх стадіях для покращення якості й подовження тривалості життя дітей.

Ключові слова: муковісцидоз; діти; особливості перебігу патології.

\section{ОСОБЕННОСТИ ТЕЧЕНИЯ МУКОВИСЦИДОЗА У ДЕТЕЙ ТЕРНОПОЛЬСКОЙ ОБЛАСТИ}

Цель исследования - установить особенности клинического течения муковисцидоза у детей Тернопольской области.

Материалы и методы. Проведен ретроспективный анализ историй болезней 15 детей Тернопольской области, больных муковисцидозом. Проведен осмотр 5 детей во время их пребывания в стационаре.

Результаты исследования и их обсуждение. Идеальными можно считать выявление больных муковисцидозом во время неонатального скрининга и начало лечения сразу же после установления диагноза даже при отсутствии клинических проявлений. Диагноз муковисцидоза у всех пациентов подтвержден в Западноукраинском специализированном детском медицинском центре. При исследовании генотипа было обнаружено различные виды мутаций, но чаще всего встречалась мутация F508del/ F508del. Мы определили, что большинство детей достигло десятилетнего возраста. Время установления диагноза муковисцидоза было разное: до 1 года - у 2 детей (13,3 \%), от 2 до 5 лет - у 5 детей (33,3 \%), от 5 до 10 лет - у 8 детей (53,4 \%). Установлено, что, чем позже у больного диагностируют заболевание, тем тяжелее его течение и ниже эффективность лечения. У этих детей отмечали многократные рецидивы воспалительных процессов в бронхах - у 10 больных (66,6 \%), придаточных пазухах носа - у 5 (33,3 \%), нарушений орункции поджелудочной железы -у 15 (100,0 \%), развитие резистентности патогенной микрофрлоры к антибиотикам - у 15 (100,0 \%). Поэтому у этих детей лечение осложнялось и, соответственно, эффрективность его снижалась. Почти у половины пациентов, а именно у 7 (46,6 \%), вследствие длительной гипоксии выявлено деформацию пальцев и ногтей в виде «барабанных палочек» и «часовых стеклышек». Легочную гипертензию диагностировано у 4 пациентов (26,6 \%). Деформацию грудной клетки (бочкообразная, расширенная в передне-заднем размере) отмечено у 7 детей (46,6 \%). Холестатический гепатит обнаружено у 5 больных (33,3 \%). Нарушение толерантности к глюкозе диагностировано у 2 детей $(13,3 \%)$.

Выводы. В структуре больных муковисцидозом детей Тернопольской области преобладали девочки и жители сельской местности. На сегодня большая часть детей области с муковисцидозом (53,3 \%) достигла возраста старше 10 лет. У детей нашего региона преобладала мутация F508del/F508del (66,7 \%). У большинства детей $(53,4$ \%) заболевание было диагностировано после 5 лет. В дебюте болезни чаще всего наблюдали затяжные обструктивные бронхиты (66,7 \%) и нарушения фуннции поджелудочной железы (100,0 \%). Среди осложнений преобладали костные десормации, признаки хронической гипоксии и высокая частота инфицирования золотистым стафилококком (73,3 \%) и синегнойной палочкой (46,7 \%). Необходимо увеличить настороженность относительно диагностики муковисцидоза на ранних стадиях для улучшения качества и увеличения продолжительности жизни детей.

Ключевые слова: муковисцидоз; дети; особенности течения патологии. 


\section{FEATURES OF COURSE OF CYSTIC FIBROSIS IN CHILDREN OF TERNOPIL REGION}

The aim of the study - to determine the peculiarities of the clinical course of cystic fibrosis in children of the Ternopil region.

Materials and Methods. A retrospective analysis of history of the diseases of 15 children of the Ternopil region, patients with cystic fibrosis was conducted. 5 children were examined during their stay in the hospital.

Results and Discussion. Ideally, detection of patients with cystic fibrosis during neonatal screening and initiation of treatment can be considered immediately after diagnosis, even in the absence of clinical manifestations. The diagnosis of cystic fibrosis in all patients is confirmed in the Western Ukrainian Specialized Children's Medical Center. In the study of the genotype, various types of mutations were detected, but the most commonly occurring mutation was F508del / F508del. We determined that most children were 10 years old. The time of diagnosis of cystic fibrosis is different: up to 1 year - in 2 children (13.3 \%); from 2 to 5 years - in 5 children (33.3\%); from 5 to 10 years - in 8 children (53.4\%). It is established that the later the patient is diagnosed with the disease, the heavier it is going through and the lower the effectiveness of treatment. In these children, multiple recurrences of inflammatory processes in bronchuses were noted - in $10(66.6 \%)$ patients, additional nasal sinuses - in $5(33.3 \%)$, pancreatic dysfunction disorders - in 15 (100.0\%), development of resistance to pathogenic microflora to antibiotics - in $15(100.0 \%)$. Therefore, in these children, treatment was complicated and, accordingly, its effectiveness was reduced. Nearly half of patients, namely 7 (46.6 \%), due to prolonged hypoxia, deformed fingers and nails in the form of "drum sticks" and "clock clocks". Pulmonary hypertension is diagnosed in 4 patients (26.6\%). Deformation of the chest (barrel, enlarged in the anterior-posterior size) was noted in 7 children (46.6\%). Cholestatic hepatitis was detected in 5 patients (33.3\%). Two children (13.3\%) were diagnosed with glucose intolerance.

Conclusions. In the structure of patients with cystic fibrosis children of the Ternopil region dominate the girls and the inhabitants of the countryside. Today, the majority of children with cystic fibrosis $(53.3 \%)$ reached the age of over 10 years. The children of our region are dominated by the mutation F508del/ F508del (66.7\%). In most children (53.4\%) the disease was diagnosed after 5 years. In the debut of the disease, protracted obstructive bronchitis (66.7 \%) and pancreatic dysfunction (100.0\%) were most often observed. Among the complications, bone deformities, signs of chronic hypoxia and a high incidence of infection with golden staphylococci $(73.3 \%)$ and blue-purulent rod $(46.7 \%)$ predominated. It is necessary to increase the caution in early diagnosis of cystic fibrosis in order to improve the quality and lengthen the life expectancy of children.

Key words: cystic fibrosis; children; peculiarities of pathology

ВстУп. Муковісцидоз - одне з найбільш розповсюджених генетично детермінованих захворювань 3 аутосомно-рецесивним типом успадкування, що зумовлені мутацією гена трансмембранного регулятора муковісцидозу, характеризуються ураженням залоз зовнішньої секреції, тяжкими ураженнями органів дихання та шлунково-кишкового тракту.

На сьогодні в Україні ця патологія є однією з найбільш серйозних та невирішених проблем сучасної медицини, пов'язаною зі значними моральними, фрізичними й матеріальними затратами сім'ї, органів охорони здоров'я і суспільства в цілому. За тяжкістю перебігу, частотою ускладнень і летальністю муковісцидоз у всьому світі займає одну з провідних позицій у структурі захворювань. У дітей раннього віку дане захворювання зумовлює поліорганну недостатність. Близько 85 \% смертності при цьому є наслідком ураження легень [1].

Муковісцидоз найчастіше трапляється серед людей європеоїдної раси. Кожен 25-й європеєць є носієм гена даного захворювання. Щороку у світі народжуються 45-50 тисяч дітей із цією патологією, а гетерозиготних носіїв налічується десятки мільйонів. Так, в Америці - 1000, Великій Британії, Франції - 500-700, Росії - 300. Різниця розповсюдженості залежно від статі не суттєва. Дуже рідко дане захворювання діагностують у представників монголоїдної раси [2].

Поширеність муковісцидозу у світі та Україні значно відрізняється (табл. 1). Найбільшу кількість випадків зареєстровано у Фінляндії, а найменшу - в Данії та Північній Ірландії. Україна займає друге місце у світі за частотою виникнення цього захворювання.

Точну частоту муковісцидозу в Україні не встановлено. За офріційними даними (2016р.), на обліку перебуває 674 дитини 3 муковісцидозом. За результатами неонатального скринінгу на муковісцидоз 2013-2014 рр., середня частота муковісцидозу в Україні становила 1:8400.
Ці дані слід вважати попередніми у зв'язку з тимчасовим припиненням 32015 р. неонатального скринінгу на муковісцидоз та недостатністю інорормації щодо популяційної частоти захворювання в Україні.

Розвиток муковісцидозу пов'язаний з мутацією гена, який розміщений на 7 хромосомі. Цей ген відповідає за синтез трансмембранного регуляторного білка муковісцидозу (ТРБМ) і фуннціонує як регульований циклічним аденозинмоносроссратом хлорний канал на апікальній поверхні епітеліальних клітин. Дитина захворіє на муковісцидоз тільки в тому випадку, якщо отримає ген від обох батьків. Якщо ген муковісцидозу має один з батьків, дитина стане лише його носієм. Ген зберігає інфрормацію про білковий канал, який регулює вхід $\mathrm{Na}^{+}$і $\mathrm{Cl}^{-}$через клітинну мембрану. Якщо інсрормація в гені пошкоджена (тобто виникла мутація гена), то білковий канал не «працює» і клітина втрачає як $\mathrm{Cl}^{-}$, так і $\mathrm{Na}^{+}$[3].

Описано більш ніж дві тисячі різновидів мутацій, найчастіше трапляється мутація F508del. Хворі на муковісцидоз, які мають в обох алелях однакові мутації, $€$ гомозиготами, а ті, які мають у двох алелях ТРБМ гена різні види мутацій, - компаундними (збірними) гетерозиготами. Батьки хворого на муковісцидоз переважно $\epsilon$ гетерозиготними носіями ТРБМ гена [4].

Таблиця 1. Поширеність муковісцидозу у світі та Україні

\begin{tabular}{|l|c|}
\hline \multicolumn{1}{|c|}{ Країна } & Частота виникнення \\
\hline Фінляндія & $1: 40000$ \\
\hline Україна & $\mathbf{1 : 8 4 0 0}$ \\
\hline Латинська Америка & $1: 5000$ \\
\hline Росія & $1: 3800$ \\
\hline Велика Британія & $1: 2500$ \\
\hline Північна Ірландія & $1: 1700$ \\
\hline Данія & $1: 1700$ \\
\hline
\end{tabular}


На початку 30-х років минулого століття, коли було вперше описано це захворювання, середня тривалість життя хворих не перевищувала 2 років. Сьогодні дана патологія піддається лікуванню [5]. Тому діагноз муковісцидозу вже не є вироком, а тривалість життя таких хворих останнім часом у багатьох розвинутих країнах світу значно зросла, що зумовлено високим рівнем надання медичних послуг. Так, у США середня тривалість життя хворих на муковісцидоз у 1970 р. становила 16 років а в 2000 р. - 32 [6]. У розвинутих країнах цей показник зростає постійно, і чим пізніше народилися такі хворі, тим якісніше лікування вони отримують, а прогнози щодо середньої тривалості їх життя суттєво покращуються. Проте середня тривалість життя українських пацієнтів удвічі менша (близько 16 років) порівняно з відповідним показником у розвинутих країнах. Така ситуація насамперед зумовлена значною кількістю невирішених на сьогодні проблем $з$ надання своєчасної та адекватної медичної допомоги Хворим на муковісцидоз.

МЕТА ДОСЛІДЖЕННЯ - ВстановитИ особливості клінічного перебігу муковісцидозу в дітей Тернопільської області.

МАТЕРІАЛИ ТА МЕТОДИ. Дизайн дослідження: проведено ретроспективний аналіз історій хвороб 15 дітей Тернопільської області, хворих на муковісцидоз. Оглянуто 5 дітей під час їх перебування у стаціонарі.

РЕЗУЛЬТАТИ ДОСЛІДЖЕННЯ ТА ЇХ ОБГОВОРЕННЯ. У структурі хворих на муковісцидоз переважали дівчатка - 9 дітей (60\%). Серед пацієнтів мешканців міста було 5 (33,33\%), села - $10(66,67 \%)$.

За віком дітей розподілили таким чином: до 1 року - 1 (6,7 \%), від 1 до 3 років - немає, від 3 до 6 років - 2 (13,3\%), від 6 до 10 років - 4 (26,7\%), старші 10 років - 8 (53,3\%) (рис. 1).

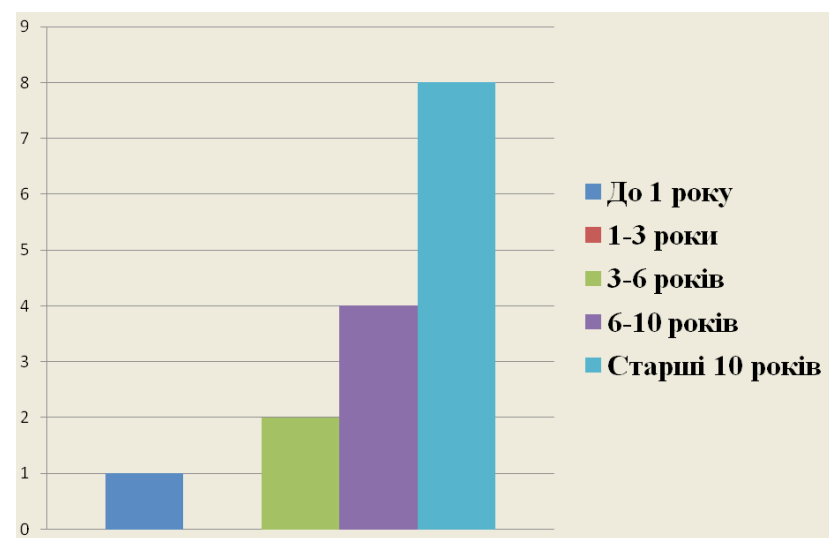

Рис. 1. Розподіл дітей за віком.

Діагноз муковісцидозу в усіх пацієнтів підтверджено в Західноукраїнському спеціалізованому дитячому медичному центрі та при дослідженні генотипу було виявлено різні види мутацій (табл. 2). Проаналізувавши результати генетичних досліджень дітей з муковісцидозом, ми виявили, що найчастіше трапляється мутація F508del/ F508del - у 10 пацієнтів (66,7 \%).

У 3 дітей (20,0 \%) перші клінічні прояви захворювання виникли протягом першого півріччя життя, у 12 (80,0 \%) - перших двох років. Час встановлення діагнозу муковісцидозу був різний: до 1 року - в 2 дітей (13,3 \%), від 2 до 5 років - у 5 дітей (33,3 \%), від 5 до 10 років - у 8 дітей (53,4 \%).

\section{Таблиця 2. Види мутацій в обстежених дітей}

\begin{tabular}{|c|l|c|}
\hline $\begin{array}{c}\text { № } \\
\text { 3a/п }\end{array}$ & \multicolumn{1}{|c|}{ Вид мутацій } & Кількість хворих \\
\hline 1 & F508del/F508del & $\mathbf{1 0}$ \\
\hline 2 & CFTRdele 2,3 (21kb) та R553 X & 1 \\
\hline 3 & F508del/185+G-T & 1 \\
\hline 4 & F508del/G542 & 1 \\
\hline 5 & F508del/621-1G-T & 1 \\
\hline 6 & F508del/R553X & 1 \\
\hline
\end{tabular}

Найбільш пізньою була діагностика муковісцидозу в однієї дівчинки, яка часто хворіла на пневмонії. Із чотирирічного віку в неї діагностовано синдром мальабсорбції, у восьмирічному віці - кістоподібні утвори підшлункової залози і лише в 9 років - муковісцидоз. За даними літератури, діагноз муковісцидозу слід вважати своєчасно встановленим протягом перших двох років життя, без ускладнень та при дуже доброму, доброму і задовільному станах хворого [2]. Звичайно, ідеальними можуть бути виявлення хворих на муковісцидоз під час неонатального скринінгу і початок лікування одразу ж після встановлення діагнозу навіть за відсутності клінічних проявів [5].

Несвоєчасне виявлення захворювання та пізно розпочате лікування призвели до розвитку ускладнень. У цих дітей відмічали багаторазові рецидиви запальних процесів у бронхах - у 10 хворих (66,6 \%), додаткових пазухах носа - у 5 (33,3 \%), порушень фрункції підшлункової залози - у 15 (100,0 \%), розвиток резистентності патогенної мікрофрлори до антибіотиків - у 15 (100,0 \%). Тому лікування в них ускладнювалось і, відповідно, ефективність його знижувалась [2].

Майже в половини пацієнтів, а саме у 7 (46,6 \%), внаслідок тривалої гіпоксії виявлено дефрормацію пальців і нігтів у вигляді «барабанних паличок» та «годинникових скелець». Легеневу гіпертензію діагностовано в 4 пацієнтів (26,6 \%). Деорормацію грудної клітки (бочкоподібна, розширена в передньо-задньому розмірі) відмічено в 7 дітей (46,6\%). Холестатичний гепатит виявлено в 5 хворих (33,3\%). Порушення толерантності до глюкози діагностовано у 2 дітей (13,3 \%) (табл. 3).

У більшості пацієнтів (73,3 \%) відмічали хронічну колонізацію Staphylococcus aureus, а в 7 (46,7 \%) - Pseudomonas aeruginosa.

Було виявлено, що в одній сім'ї у трьох дітей діагностовано муковісцидоз, а одна дитина померла до 1 року.

Встановлено, що, чим пізніше у хворого діагностують муковісцидоз, тим тяжчий його перебіг і нижча ефективність лікування.

Лікування - антибіотикотерапія (амоксиклав, ципрофлоксацин, тобраміцин). Усі діти додатково приймали сіль (віком до 3 років - 2-3 г/добу, старші 3 років - 3-5 г/добу), фрерменти підшлункової залози (креон), урсофальк, щоденно - муколітики (ацетилцистеїн, карбоцистеїн амброксолу гідрохлорид), періодично - полівітамінні комплекси.

Таким чином, перебіг муковісцидозу характеризується наявністю ознак хронічної гіпоксії та призводить до розвитку різноманітних ускладнень з боку інших органів і систем організму. 
Таблиця 3. Критерії муковісцидозу в дітей

\begin{tabular}{|c|c|c|c|c|c|c|c|c|c|c|c|c|c|c|c|}
\hline \multirow{5}{*}{ Симптом } & \multicolumn{15}{|c|}{ Пацієнти (n=15) } \\
\hline & \multicolumn{15}{|c|}{ вік дитини } \\
\hline & $\begin{array}{c}11 \\
\text { років } \\
\end{array}$ & \begin{tabular}{|c|}
5 міся- \\
ців
\end{tabular} & $\begin{array}{c}6 \\
\text { років }\end{array}$ & \begin{tabular}{c|}
12 \\
років
\end{tabular} & $\begin{array}{c}17 \\
\text { років }\end{array}$ & $\begin{array}{c}10 \\
\text { років }\end{array}$ & $\begin{array}{c}11 \\
\text { років }\end{array}$ & $\begin{array}{c}15 \\
\text { років }\end{array}$ & $\begin{array}{c}5 \\
\text { років } \\
\end{array}$ & $\begin{array}{c}10 \\
\text { років }\end{array}$ & $\begin{array}{c}13 \\
\text { років }\end{array}$ & $\begin{array}{c}15 \\
\text { років }\end{array}$ & $\begin{array}{c}7 \\
\text { років } \\
\end{array}$ & \begin{tabular}{|c|}
11 \\
років
\end{tabular} & $\begin{array}{c}13 \\
\text { років }\end{array}$ \\
\hline & \multicolumn{15}{|c|}{ час встановлення діагнозу } \\
\hline & 4 роки & $\begin{array}{c}4 \\
\text { місяці }\end{array}$ & $\begin{array}{c}6 \\
\text { років }\end{array}$ & $\begin{array}{c}1 \\
\text { рік }\end{array}$ & $\begin{array}{c}6 \\
\text { років }\end{array}$ & \begin{tabular}{|c|}
8 \\
років
\end{tabular} & $\begin{array}{c}5 \\
\text { років }\end{array}$ & $\begin{array}{c}7 \\
\text { років }\end{array}$ & $\begin{array}{c}4 \\
\text { роки }\end{array}$ & $\begin{array}{c}6 \\
\text { років }\end{array}$ & $\begin{array}{c}7 \\
\text { років }\end{array}$ & $\begin{array}{c}6 \\
\text { років }\end{array}$ & $\begin{array}{c}2 \\
\text { роки }\end{array}$ & \begin{tabular}{|c|}
9 \\
років
\end{tabular} & $\begin{array}{c}5 \\
\text { років }\end{array}$ \\
\hline Генетична мутація* & 1 & 2 & 1 & 1 & 3 & 1 & 4 & 5 & 1 & 6 & 1 & 1 & 1 & 1 & 1 \\
\hline Потова проба, мЕкв/л & 148 & 84 & 106 & 93 & 102 & 96 & 108 & 95 & 101 & 89 & 104 & 92 & 112 & 92 & 97 \\
\hline $\begin{array}{l}\text { Десрормація грудної } \\
\text { клітки }\end{array}$ & + & + & & + & + & + & + & + & & & & & & & \\
\hline $\begin{array}{l}\text { Відставання у } \\
\text { фізичному розвитку }\end{array}$ & + & & & & & + & & & + & & & & + & & + \\
\hline «Барабанні палички» & & & + & + & & + & & + & & & + & & & + & + \\
\hline $\begin{array}{l}\text { «Годинникові } \\
\text { скельця» }\end{array}$ & & & + & + & & + & & + & & + & & & & + & + \\
\hline Легенева гіпертензія & & & & & & + & & & & & + & & + & & + \\
\hline $\begin{array}{l}\text { Холестатичний } \\
\text { гепатит }\end{array}$ & & & + & & + & & & + & & & + & & & & + \\
\hline $\begin{array}{l}\text { Iнсрікованість } \\
\text { Staphylococcus } \\
\text { aureus }\end{array}$ & + & & + & + & + & & + & + & & + & + & + & & + & + \\
\hline $\begin{array}{l}\text { Iнсрікованість } \\
\text { Pseudomonas } \\
\text { aeruginosa }\end{array}$ & & & + & & + & + & & + & & & + & + & & + & \\
\hline $\begin{array}{l}\text { Порушення } \\
\text { толерантності до } \\
\text { глюкози }\end{array}$ & & & & & & & & & + & & & + & & & \\
\hline $\begin{array}{l}\text { Порушення нервово- } \\
\text { психічного розвитку }\end{array}$ & & & & + & + & & & & & & & & & & \\
\hline
\end{tabular}

Примітка. * - відповідно до нумерації в таблиці 2.

ВИСНОВКИ. 1. У структурі хворих на муковісцидоз дітей Тернопільської області переважають дівчатка та мешканці сільської місцевості.

2. На сьогодні більша частина дітей області з муковісцидозом (53,3 \%) досягла віку старше 10 років.

3. У дітей нашого регіону переважає мутація F508del/ F508del (66,7 \%).

4. У більшості дітей $(53,4 \%)$ захворювання було діагностовано після 5 років.

5. У дебюті хвороби найчастіше спостерігали затяжні обструктивні бронхіти (66,7 \%) та порушення функції підшлункової залози (100,0%).

\section{СПИСОК ЛІТЕРАТУРИ}

1. Ивкина С. С. Муковисцидоз у детей / С. С. Ивкина, Л. В. Кривицкая, Т. А. Латохо // Проблемы здоровья и экологии. - 2015. - № 4 (46). - С. 90-96.

2. Bush A. Cystic fibrosis / A. Bush, M. Gotz // Eur. Resp. Mon. - 2006. - Vol. 15. - P. 234-289.

3. Гошовська І. І. Муковісцидоз у дітей: патоморфологічні особливості / І. І. Гошовська, Ю. І. Кузик, Н.А.Гошовська // Вісн. наук. дослідж. - 2015. - № 4. - С. 29-32.
6. Серед ускладнень переважали кісткові десрормації, ознаки хронічної гіпоксії та висока частота інфрікування золотистим стафрілококом (73,3 \%) і синьогнійною паличкою $(46,7 \%)$.

7. Необхідно збільшити настороженість щодо діагностики муковісцидозу на ранніх стадіях для покращення якості й подовження тривалості життя дітей.

ПЕРСПЕКТИВИ ПОДАЛЬШИХ ДОСЛІДЖЕНЬ - ОЦінити якість життя дітей з муковісцидозом після проведеного лікування протягом 6 місяців, визначити залежність між видом мутації та якістю життя пацієнтів.

4. Муковісцидоз у дітей: помилки ранньої діагностики та їх аналіз / О. М. Охотнікова, Ю.І.Гладуш, Т. П. Іванова [та ін.] // Клініч. імунологія. Алергологія. Інсректологія. - 2013. - T. 64, № 5. - C. 15-21.

5. The impact of early cystic fibrosis diagnosis on pulmonary function in children / S. S. Wang, L. A. O'Leary, S. C. Simmons, M. J. Khoury // J. Pediatr. - 2002. - Vol. 141. - P. 804-810.

6. Hodson M. Cystic fibrosis / M. Hodson, G. Duncan, A. Bush // Cystic fibrosis. Third edition London: Edward Arnold (Publishers)Ltd. - 2007. - P. 477. 


\section{Педіатрія}

\section{REFERENCES}

1. Ivkina, S.S., Krivitskaya L.V., \& Latokho, T.A. (2015) Mukovystsydoz u detey [Cystic fibrosis in children]. Problemy zdorovya $i$ ekologii - Health and Ecology Problem, 4 (46), 9096 [in Russian].

2. Bush, A., \& Gotz, M. (2006) Cystic fibrosis. Eur. Resp. Mon., 15, 234-289.

3. Hoshovska, Yu.I., \& Kuzyk, N.A. (2015). Mukovytsydoz u ditei: patomorfolohichni osoblyvosti [Cystic fibrosis in children: pathomorphological features]. Visnyk naukovykh doslidzhen Bulletin of Scientific Research, 4, 29-32 [in Ukrainian].
4. Okhotnikova, O.M., Hladush, Yu.I., \& Ivanova, T.P. (2013). Mukovystsydoz u ditei: pomylky rannioi diahhnostyky ta yikh analiz [Cystic fibrosis in children: early diagnosis errors and their analysis]. Klinichna imunolohiia. Alerhholohiia. Infektolohiia - Clinical Immunology. Allergology. Infectology, 5, 64. 15-21.

5. Wang, S.S., O'Leary, L.A., Simmons, S.C. \& Khoury, M.J. (2002). The impact of early cystic fibrosis diagnosis on pulmonary function in children. J. Pediatr., 141, 804-810.

6. Hodson, M., Duncan, G., \& Bush, A. (2007). Cystic fibrosis. Third edition London: Edward Arnold (Publishers). Ltd. 